\title{
Robert Boyle's Memoirs for the Natural History of Human Blood (1684): Print, Manuscript and the Impact of Baconianism in Seventeenth-Century Medical Science
}

\author{
HARRIET KNIGHT and MICHAEL HUNTER*
}

\section{Introduction}

Robert Boyle's Memoirs for the natural history of human blood, which appeared in its first and only edition in 1684, is a well-known but much misunderstood book. In this paper, we will argue that a consideration of its history before and after its publication is not only significant in itself but also does much to enhance our understanding of Boyle's intellectual method, and especially the implications of his commitment to Baconianism and his attitude to print as a medium.

Alone among modern commentators, Boyle's bibliographer John Fulton praised the Natural history of human blood as "the most important of Boyle's medical writings", claiming that it heralded "the beginning of physiological chemistry". Fulton regarded the observations that it contained as "new and always original" and saw the tract as anticipating the work of Justus von Liebig and Johann Christian Poggendorff in the nineteenth century. ${ }^{1}$ In general, however, critical opinion of Human blood has been less complimentary. Lynn Thorndike dismissed the work as "a disappointing treatise". 2 A Rupert Hall showed that many of Boyle's findings had been published by others before 1684, and criticized Boyle for failing to present a systematic treatise or to "make sense of" the experiments he published by drawing conclusions from his results. ${ }^{3}$ The most recent, and most sustained, study of Boyle's work on blood, by Johannes Büttner, has also presented it as an untimely publication, outdated when it was printed, isolated from contemporary research, not worked into a systematic framework, and overestimating the usefulness of dry distillation; Büttner nevertheless acknowledged the crucial importance of its assertion that blood could be subjected to chemical analysis, and its sophisticated treatment of chemical reagents. ${ }^{4}$

(C) Harriet Knight and Michael Hunter 2007

*Dr Harriet Knight, BA, MPhil, PhD, Centre for Editing Lives and Letters, Queen Mary, University of London, Mile End Road, London, E1 4NS, UK. Professor Michael Hunter, MA, DPhil, School of History, Classics and Archaeology, Birkbeck, University of London, Malet Street, London, WC1E 7HX, UK.

We are grateful to Peter Anstey and to the anonymous reviewers for Medical History for their helpful comments on a draft of this article, and to the library and archive staff of the Royal Society for their assistance in our work on the Boyle manuscripts.

\footnotetext{
${ }^{1}$ John Farquhar Fulton, A bibliography of the Honourable Robert Boyle, 2nd edn, Oxford, Clarendon Press, 1961, p. 99.

${ }^{2}$ Lynn Thorndike, $A$ history of magic and experimental science, 8 vols, New York, Columbia University Press, 1958, vol. 8, p. 193.

${ }^{3}$ A Rupert Hall, 'Medicine and the Royal Society', in A G Debus (ed.), Medicine in seventeenth century England: a symposium held at UCLA in honour of CD O'Malley, Berkeley and London, University of California Press, 1974, pp. 421-51, on pp. 447-50.

${ }^{4}$ Johannes Büttner, 'Die Physikalische und Chemische Untersuchung von Blut im 17 und 18 Jahrhundert: Zur Bedeutung von Robert Boyle's "Memoirs for the Natural History of Human Blood"
} 


\section{Harriet Knight and Michael Hunter}

This paper will show that an account of the book's history goes some way to explaining the shortcomings for which Boyle has been so criticized. It is clear from Human blood itself that, although he published it in book form, Boyle was acutely aware of its defects. He identified these failings within the printed book, and, as we will show, he took steps to supply the imperfections of the printed text almost immediately after its publication. These signs of Boyle's dissatisfaction have not previously been taken seriously, because it has been presumed that, as a printed work, the Memoirs for the natural history of human blood must have been intended as a definitive statement on its subject. By contrast, this paper will argue that-although it is true that in 1684 Boyle issued in printed form research which he had carried out some two decades earlier, insofar as he could salvage it from among his papers - he knew that his contribution was outdated and that he had failed to revise it for the press as fully has he might have done. In fact, far from representing the culmination of his attention to the topic, Boyle seems to have seen the publication of the book as an appropriate stimulus to further work on human blood, both by others and himself, which began within months of the appearance of the printed work.

These findings raise significant questions about Boyle's attitude to print which we will sketch here, but which need to be further pursued. ${ }^{5}$ Though Boyle's reputation was largely derived from the printed works that he brought out from 1660 onwards, he seems to have been rather ambivalent towards the medium, often postponing publication of his writings and sometimes putting into print materials that he regarded as provisional in order to establish priority and to circulate information as a means both of ensuring its survival and of encouraging others to extend the work that he had begun. Scholars have often been rather puzzled by the latter practice, largely due to an assumption that print was the ultimate goal of natural philosophical research because of the "fixity" that it entailed; they have been accordingly critical of Human blood. However, Boyle's practice challenges that presumption, suggesting that, in an ongoing project like this, the boundary between what was printed and what was not was a fluid one. In fact, in a case like this where an author produced a publication which he did not live to supersede, a comprehensive study both of the rationale of the book itself, and of its author's manuscript remains, may give a quite different view both of the role of print and of contemporary perceptions of it.

\section{The Background to Human Blood (1684)}

Boyle's interest in blood was sustained over several decades, beginning in the mid-late 1650 s and continuing, with periodic lapses, until his death in 1691. Its earliest phase is witnessed by various passages on the topic in his Usefulness of natural philosophy, written in the late 1650s and published in 1663. This also records Boyle's provision of facilities for Christopher Wren's experiment for injecting liquors into the veins of a dog. ${ }^{6}$ In the 1660 s,

(1684)', Medizin Historisches Journal, 1987, 22: 185-96. E Hackett describes Boyle's researches into blood in 'Robert Boyle and the human blood', Irish J. med. Sci., 1950, 6: 528-33.

${ }^{5}$ See below, pp. 163-4. This subject was further explored by Harriet Knight in 'Designed instability: Robert Boyle's works in manuscript and print', a paper presented at 'Sitting on the Cat', a symposium held on 3 June 2006 at Queen Mary, University of London, to be published in a volume based on the symposium edited by Alison Wiggins.

${ }^{6}$ See The works of Robert Boyle, ed. Michael Hunter and Edward B Davis, 14 vols, London, Pickering \& Chatto, 1999-2000, vol. 3, pp. 327-9 and 


\section{Robert Boyle's Memoirs for the Natural History of Human Blood}

Boyle carried out investigations into blood in collaboration with researchers in Oxford including Thomas Willis, Richard Lower, Walter Needham and John Locke. ${ }^{7}$ At this point, Boyle was dividing his time between London and Oxford, and his interest in blood is evident in his correspondence as he moved between the two. For example, in June 1664 Lower wrote to Boyle, noting his intention of performing a transfusion between two dogs and of investigating the difference in colour between arterial and venal blood, and recording the results of injecting milk into a dog's vein. ${ }^{8}$ When Boyle returned to Oxford two months later, he became involved in Lower's investigations, and, back in London in December, he reported several Oxford experiments to the Royal Society. ${ }^{9}$ Boyle's continuing prominence in the field was implied in November 1665 when the Philosophical Transactions recounted that a French physician's claim to have found milk rather than blood in the veins had been referred to Boyle for verification. ${ }^{10}$

Between April and September 1666 Boyle repeatedly acted as an intermediary between Lower and the Royal Society, reporting on Lower's progress towards animal-to-animal transfusions. ${ }^{11}$ In April 1666 Boyle also reported his own fatal attempt to feed a dog by injecting broth directly into its veins. ${ }^{12}$ Following a series of Royal Society transfusions in the autumn of 1666, Boyle suggested various improvements to the experiments at meetings throughout December. ${ }^{13}$ The Philosophical Transactions for February 1667 included a list of queries proposed by Boyle for consideration in animal-to-animal transfusions. ${ }^{14}$ In March he proposed bleeding some animals to death to discover how much blood they contained, and although his interventions are less clear as the Royal Society embarked on a sustained and gruesome set of trials throughout 1667, Henry Oldenburg sent a detailed account of the first human transfusion performed on Arthur Coga to Boyle on 25 November. ${ }^{15}$

These injection and transfusion experiments were linked to the issue of the nature of the blood, in which Boyle was clearly also interested at this point, reporting experiments on the effects of acidic and other substances on the blood to the Royal Society in 1664; a handful of related experiments are recorded in one of his workdiaries dating from the late $1660 \mathrm{~s} .{ }^{16}$

$\overline{\text { passim }}$ (hereafter Works). Boyle's patronage was also emphasized when Wren's experiment was

recapitulated in Philos. Trans., 1665, 1: 128-30. See also Works, vol. 5, p. xxxvii.

${ }^{7}$ On research into blood in this period, see Robert $\mathrm{G}$ Frank Jr., Harvey and the Oxford physiologists: scientific ideas and social interaction, Berkeley and London, University of California Press, 1980; W C Gibson, 'The biomedical pursuits of Christopher Wren', Med. Hist., 1970, 14: 331-41; A Rupert Hall and Marie Boas Hall, 'The first human blood transfusion: priority disputes', Med. Hist., 1980, 24: 461-5; Pete Moore, Blood and justice, Chichester, John Wiley and Sons, 2003.

${ }^{8}$ Lower to Boyle, 8 and 24 June 1664, The correspondence of Robert Boyle, ed. Michael Hunter, Antonio Clericuzio and Lawrence M Principe, 6 vols, London, Pickering \& Chatto, 2001, vol. 2, pp. 277-91 (hereafter Correspondence).

${ }^{9}$ Frank, op. cit., note 7 above, pp. 183-5. The minutes of the Royal Society for 21 Dec. 1664 include a report from Boyle, which recounts, among others, an experiment "of putting volatile and acid salts into warm sheep's blood" and records that while the former preserved and sometimes brightened blood, the latter darkened and congealed it. Thomas Birch, History of the Royal Society, 4 vols, London, for A Millar, 1756-7, vol. 1, p. 509.

${ }^{10}$ Philos. Trans., 1665, 1: 100-1. See also Works, vol. 5, pp. 499-500.

${ }^{11}$ Birch, op. cit., note 9 above, vol. 2, pp. 83-4, 98, 115. Boyle's involvement as emissary was also emphasized when the experiment was reported in Philos. Trans., 1666, 1: 353-8. See also Works, vol. 5, pp. 540-3.

${ }^{12}$ Birch, op. cit., note 9 above, vol. 2, p. 84 .

${ }^{13}$ Ibid., pp. 132-4.

${ }^{14}$ Philos. Trans., 1667, 1: 385-8. See also Works, vol. 5, pp. 544-6.

${ }^{15}$ Birch, op. cit., note 9 above, vol. 2, p. 162; Correspondence, vol. 3, pp. 368-9.

${ }^{16}$ Birch, op. cit., note 9 above, vol. 1, p. 509; The workdiaries of Robert Boyle, ed. Michael Hunter, http://www.livesandletters.ac.uk/wd/, Workdiary 


\section{Harriet Knight and Michael Hunter}

In addition, Boyle referred in the preface to his 1684 book to a set of inquiries on blood which he had drawn up and circulated "many years ago", presumably in the 1660s. No copy of this document of so early a date survives in the Boyle Papers, but a copy of a list of heads on blood which is almost certainly related to it exists in a notebook of Locke dating from this period. ${ }^{17}$

The Royal Society's interest in blood was sustained through 1668 and into 1669, with investigations into injection and transfusion, the colour of blood passing through the lungs, the pulse and other topics. ${ }^{18}$ However, the focus of Boyle's contributions shifted at this point to the consideration of light and air: his experiments on these were read to the Society on 28 November and 5 December 1667, while in April 1668 he identified air as having been his main preoccupation during his absence from meetings over the previous months, and his contributions to the Society that summer dealt mainly with issues concerning pneumatics, the subject of the "continuation" to his first scientific publication which came out the following year. ${ }^{19}$

After 1670, when Boyle suffered a stroke, his attendance at the Royal Society became less frequent, and he does not appear to have been involved in the two substantial advances made in the understanding of blood by men associated with the Royal Society during the 1670s. The first of these was Antoni van Leeuwenhoek's microscopic investigation of the composition of blood, published in the Philosophical Transactions in $1674 .{ }^{20}$ Further communications on this topic in 1678 led Robert Hooke and Edmund King to carry out related experiments under the Society's auspices. ${ }^{21}$ The other major innovation came from Walter Needham in a long paper on the serum of the blood presented to the Royal Society in $1675 .^{22}$ Neither of these developments was taken into account in Boyle's published work on blood. It is worth noting in this context that Oldenburg's list of "such papers, as were mentioned to me by the Honourable Robert Boyle March. 26. 1677", which enumerates his unpublished writings, makes no mention of his research into human blood, perhaps confirming that he was not working on it at this time. ${ }^{23}$

21-205, 206, 207 and 208 (hereafter WD). The first of these (only) was used in the materials for the second edition: Royal Society Boyle Papers 18, fol. 18 (hereafter BP), published in Michael Hunter and Harriet Knight (eds), Unpublished material relating to Robert Boyle's 'Memoirs for the natural history of human blood', Robert Boyle Project Occasional Papers, No. 2, Birkbeck, University of London, Robert Boyle Project, 2005 (available at http://www.bbk.ac.uk/boyle),

p. 5 (see also p. x) (hereafter Unpublished material).

${ }^{17}$ Works, vol. 10, p. 5; Bodleian Library, MS Locke f. 19 , pp. 272-3, 302-3. The first section of these (pp. 272-3) bears a fairly close relation to the heads printed by Boyle in 1684: the second part (pp. 302-3) consists of more detailed heads, none of which recur in Human blood. For an edition of this document, see Unpublished material, pp. 19-20. Pages 272-3 are reproduced and Locke's notes discussed in Kenneth Dewhurst, 'Locke's contribution to Boyle's researches on the air and on human blood', Notes and Records of the Royal Society (hereafter NRRS), 1962, 17: 198-206, on pp. 201-2 and plate 12. Some of Dewhurst's inferences on the significance of the notebook are questioned by Guy Meynell, 'Locke, Boyle and Peter Stahl', NRRS, 1995, 49: 185-92 on p. 185. Locke's investigation of blood, as evidenced by his notebooks, is also discussed by Frank, op. cit., note 7 above, pp. 186-7 and 337.

${ }^{18}$ Birch, op. cit., note 9 above, vol. 2, pp. 235-7, 241, 250, 255-6, 259, 261, 274, 281, 288, 296, 306, 312, $316,339,341,356-8$.

${ }^{19}$ Ibid. pp. 216-7, 224-5, 273-4, 276. Cf. pp. 283, 285, 287, 298, 312, and Works, vol. 6, pp. xi, xv-vi. For year-by-year details of Boyle's attendance at the Royal Society and his absences (including July 1667-April 1668, Aug. 1668-Jan. 1669 and July 1669-March 1670), see Michael Hunter, 'Robert Boyle and the early Royal Society: a reciprocal exchange in the making of Baconian science', Br. J. Hist. Sci., 2007, 40: 1-23, on p. 3.

${ }^{20}$ Philos. Trans., 1674, 9: 23-5, 121-31.

${ }^{21}$ Birch, op. cit., note 9 above, vol. 3, pp. 374-5, 379-80, 383.

${ }^{22}$ Ibid., pp. 233-41.

${ }^{23}$ Works, vol. 14, pp. 337-9. 


\section{Robert Boyle's Memoirs for the Natural History of Human Blood}

There is, however, evidence that Boyle returned to his work on blood in the early 1680s. An inventory of the contents of two boxes dating from c.1680 includes "A Purple Paper about humane Bloud \&c.": although this might simply itemize papers surviving from the 1660 s, it might equally allude to more recent work. ${ }^{24}$ More significant are two lists of "heads" concerning human blood which almost certainly date from this time. One, entitled "Heads of the History of human blood", is in the hand of Hugh Greg, who began working for Boyle c.1680; it is the earliest clear evidence that blood was again being studied as a topic in its own right. It represents an intermediate stage between the "heads" recorded by Locke in the 1660s and those published in 1684, from which it differs substantially, primarily in that its categories are narrower and more specific. ${ }^{25}$ In addition, there is a list in the hand of another amanuensis, Robin Bacon, which bears a much closer relationship to the heads as printed in $1684 .{ }^{26}$

An equally interesting clue concerning Boyle's interest in blood in the early 1680s is provided by another document in the hand of Greg, "An Index of the Chapters of the Experimenta et Observationes Physicæ". ${ }^{27}$ The work referred to, Experimenta et observationes physicae, was eventually published in 1691, and as it materialized in print at that point it was a repository for experimental material — often of an earlier date — which Boyle considered worth preserving but which was not sufficiently extensive to merit book publication in its own right. This is the earliest extant list of its contents, and, in addition to various chapters of "promiscuous", "Chymico-magneticall" and "Chymical" experiments, trials on the loadstone and the like which did ultimately appear in the published book in 1691, this also lists "various Experiments of the Spirit of human blood" and "various Tryalls made of the serum of a healthy mans blood". ${ }^{28}$ It is not entirely clear when the experiments in question were made, but they probably date from the $1660 \mathrm{~s}$, as was the case with other components that went into Experimenta et observationes physicae. ${ }^{29}$ At this point, then, Boyle had clearly reverted to an interest in blood, but he saw his findings as suitable only for anthologizing in this way, perhaps because he was himself aware of his lack of involvement in the developments in the 1670s which left his earlier findings rather high and dry. In spite of this, however, in 1684 he brought out his Memoirs for the natural history of human blood and the material on blood was removed from all subsequent synopses of Experimenta et observationes physicae. ${ }^{30}$

This begs the question, why did Boyle collate his work on blood and present it in print at this particular time? In other cases, he seems to have been impelled into print by getting wind of other people writing on related topics, sometimes invoking this to explain why his collections of earlier writings ignored more recent work on the subject: an instance of

\footnotetext{
${ }^{24}$ Ibid., p. 340.

${ }^{25}$ BP 18, fols. 43-4; Unpublished material, pp. 20-1 (this publication provides an edition of all of these lists, and a table collating the main versions). On the variety of hands in the Boyle archive and their significance in aiding dating, see Works, vol. 1, pp. c-cii, and The Boyle Papers: understanding the manuscripts of Robert Boyle by Michael Hunter with contributions by Edward B Davis, Harriet Knight, Charles Littleton and Lawrence M Principe,

Aldershot, Ashgate, 2007, ch. 1.
}

\footnotetext{
${ }^{26}$ BP 18, fol. 48; Unpublished material, pp. 21-3.

${ }^{27} \mathrm{BP} 36$, fol. 95 .

${ }^{28}$ For Experimenta et observationes physiciae, see Works, vol. 11, pp. 367-426. The other item in the BP 36, fol. 95 contents list that was ultimately published elsewhere is 'Vitiated sight', published with Final causes in 1688; Works, vol. 11, pp. 153-66.

${ }^{29}$ See Works, vol. 11, pp. liv-lxi.

${ }^{30}$ These are itemized in Hunter, et al., op. cit., note 25 above, p. 187 , n. 31.
} 


\section{Harriet Knight and Michael Hunter}

comparable date is his Short memoirs for the natural experimental history of mineral waters (1685). ${ }^{31}$ This is symptomatic of a notorious sensitivity on Boyle's part about being given proper credit for his work, seen in various episodes during his career. ${ }^{32}$ In the case of Human blood, the importance to Boyle of registering the exact date of publication is suggested by the fact that a cancel was substituted for the original title-page specifying that the work was published in 1683/4 as against 1684. ${ }^{33}$ However, unless Boyle knew of some planned publication which failed to materialize and of which we are ignorant, this does not seem to be the reason here. ${ }^{34}$ The stimulus to publication to which Boyle does refer in his preface involves Locke, whose "laudable design" is mentioned, and to whose initiative the book is attributed. However, although Locke is known to have had a long-term interest in related topics-for instance, it was he who reviewed Boyle's Of the reconcileableness of specifick medicines to the corpuscular philosophy in the Bibliothèque Universelle in 1686 - there is no evidence that he played a special role at this point. In any case, in the latter part of 1683 when Boyle was apparently getting the book ready for the press-as witnessed by the date of 22 December 1683 which appears at the end of the text-Locke had just gone into exile in Holland and probably had other things on his mind. ${ }^{35}$

An alternative scenario is that Boyle's decision to publish his findings on blood at this point was due to the mutual relationship between this project and another one. In Usefulness, Boyle had combined his speculations about the blood and other aspects of the human body with an interest in medical practice which he had pursued in the 1660 s by compiling an open attack on the orthodox "methodus medendi". Little is heard of this in the period after his move to London in 1668 until the late 1670s, when he seems to have returned to work on it: it is referred to in the 1677 list of writings by Oldenburg from which Human blood is absent, and certain manuscripts relating to it date from around 1680, including a section of text which is critical of the excessive bleeding of patients. However, some time early in the 1680s Boyle abandoned this work for various reasons, instead adopting the strategy of publishing books, such as Human blood, which canvassed the contribution that could be made to medicine by chemical and other investigations. ${ }^{36}$

\footnotetext{
${ }^{31}$ Works, vol. 10, p. xxix. See also, for example, Works, vol. 7, pp. xi-xii, xviii, 5-6, 77,334; vol. 8, p.xv.

${ }^{32}$ See Works, vol. 1, pp. 1xxvi-lxxxi; Michael Hunter, Robert Boyle (1627-91): Scrupulosity and science, Woodbridge, Boydell Press, 2000, pp. 137-8, 219-21.

${ }^{33}$ There are two states of the title-page of Human blood, one, identified by Fulton as the original issue, dated 1684 (Fulton 146A) and the other with a cancelled title-page, which differs only in being dated " $1683 / 4$ ". Fulton proposes the latter as the preferred state on the basis that it is the version used in the copy presented to Newton by Boyle; that this is correct is suggested by the fact that the copies presented to the Royal Society and Bodleian Library (8o N 50 Med) and Martin Lister's copy (Bodleian Library Ashm. C 38) all share this state. See Works, vol. 10, p. xvi, and Fulton, op. cit., note 1 above, pp. 100-1.

${ }^{34}$ For the possible significance in this connection of Philip Guide's De la vertue singulière du vin rouge,
}

pour guerir le retention d'urine (1684), see Works, vol. 10, p. xvi n. In his book (which takes the form of a letter to Boyle dated 2 March 1683/4), Guide acknowledges receipt of a copy of Boyle's work.

${ }^{35}$ See Works, vol. 10, pp. xii, 5-6, 97 (it is worth clarifying that these references suggest that the initiative on the part of Locke was a recent one, as against the alternative possibility that Boyle was attributing his initial investigations in the 1660 s to Locke's interest in the topic). See also ibid., pp. xliv-xlv, and J L Axtell, 'Locke's review of the Principia', NRRS , 1965, 20: 152-61, on p. 152. It is perhaps worthy of note that 1683 was the publication date of the only example of a second edition of a work by Boyle with a substantive appendix, his New experiments touching cold. See Works, vol. 4, pp. xxixxii, 543-75.

${ }^{36}$ For all this, see Hunter, Scrupulosity, op. cit., note 32 above, ch. 8 (incl. pp. 196-8 on the abuse of bleeding; though see also p. 194). 


\section{Robert Boyle's Memoirs for the Natural History of Human Blood}

That the writing up of Human blood for publication was linked to the abandonment of Boyle's critique of orthodox medical practice is suggested by various pieces of evidence. Boyle's preface to Human blood gives a medical imperative for his investigations: "the Mass of Blood being either vitiated, or (which is often the effect of that Depravation) disorderly mov'd, is the Seat of divers, and the Cause of most Diseases, whose cure consequently depends mainly upon the rectifying of the Blood". ${ }^{37}$ It is also revealing that one of the lists of heads for Human blood from the early 1680s appears on the recto of a leaf whose verso contains a synopsis of the suppressed polemic (it also contains a list of heads concerning sense, reason and authority). ${ }^{38}$ The putative insertion of relevant material into Experimenta et observationes physicae might have been a transitional stage, since the published version of that book does include material from the suppressed medical work, with an apologetic statement to this effect. Indeed, a further link is provided by the fact that Boyle there stated that he was handing over such subjects for study to a young doctor called "Trallianus" (whose identity it has unfortunately proved impossible to establish), and a list of topics recommended to "Trallianus" for study which appears in a notebook dating from Boyle's later years was topped by "The History of the Liquors of the Body, as blood, chyle, serum, lympha, gaul, succus pancreaticus, etc". This list also includes other topics relating to the research agenda of Human blood, including the analysis of bodily secretions like urine. ${ }^{39}$ Though not explaining Boyle's evident sense of urgency about getting the book into print, the relationship to the suppressed work provides the most convincing background to Boyle's return to an interest in this topic at this time.

\section{Boyle's Memoirs for the Natural History of Human Blood (1684)}

Whatever the exact stimulus to Boyle's publication of his longstanding if somewhat sporadic researches into blood in 1684, it is appropriate to turn to Human blood itself in order better to understand Boyle's rationale in putting his materials into print in this way at this point. As noted above, modern commentators have criticized Boyle's work as outdated at the time of publication, and as disorganized. We will see that Boyle's preface explicitly warns his readers of both "defects"; it also proposes a rationale for the use of print not to enshrine finalized knowledge but as a spur to future research, in which the presentation of unsystematic, incomplete research is therefore acceptable. A Rupert Hall dismisses Boyle's preface as "a particularly tedious example of his customary apologies for lost papers and inconclusive experiments". ${ }^{40}$ However, we will argue that it offers a more or less literal

${ }^{37}$ Works, vol. 10, p. 5.

${ }^{38}$ BP 18, fol. 48; Unpublished material, pp. 21-3. See also ibid., p. xii, and Hunter, Scrupulosity, op. cit., note 32 above, pp. 166-7.

${ }^{39}$ Works, vol. 11, pp. 397-8; Hunter, Scrupulosity, op. cit., note 32 above, pp. 172-4. For the list (from MS 186, fols. 19v-20), see B B Kaplan, 'Divulging of useful truths in physick': the medical agenda of Robert Boyle, Baltimore, Johns Hopkins University Press, 1993, pp. 152-3. It seems unlikely that Trallianus could be Locke (b. 1632).

${ }^{40}$ Hall, op. cit., note 3 above, p. 447. Boyle's apologetic tone in this preface is indeed characteristic.
The question of how literally to take Boyle's apologetic prefaces has been frequently addressed, with Shapin and Schaffer reading them as careful constructions designed to present Boyle as the model experimental philosopher, and Johns on the other hand reading them as literal accounts of the problems of the seventeenthcentury book trade: Steven Shapin and Simon Schaffer, Leviathan and the air-pump: Hobbes, Boyle and the experimental life, Princeton University Press, 1985, pp. 63-6; Steven Shapin, A social history of truth, University of Chicago Press, 1994, pp. 175-80; Adrian Johns, The nature of the book: print and knowledge in the making, University of Chicago Press, 


\section{Harriet Knight and Michael Hunter}

account of the volume's genesis, indicating Boyle's clear sense of the shortcomings of the printed work, yet providing a methodological framework within which the volume's oddities can be understood.

Boyle's preface (which is addressed to Locke) opens by warning the reader that his research is long outdated. It is "many years" since he "propounded to some Ingenious Physicians a History of the Fluid parts of the Body ... and did particularly draw up a set of Enquiries, and make divers Experiments in reference to the Blood". In the intervening period, he has lost both his papers and his memory of the experiments, and has also become less "conversant with Medicinal Subjects" than he was. This leaves him "unable to contribute any thing considerable" to Locke's "laudable design", but prepared to comply to the best of his ability: "all this is said, not to excuse me from obeying you at all, but to excuse me for obeying you so unskilfully". "As we have seen, Boyle's claim to have been working on blood "many years ago" can be externally verified, while his failure to include developments made in the 1670s suggests the veracity of his claim that the papers have been "since lost" or at least neglected. Moreover, his awareness of the volume's serious shortcomings, which might read like empty rhetorical modesty, is borne out by the surviving evidence (discussed below) of Boyle's attempts to improve upon the printed version of the work.

Boyle's prefatory materials directly address his failure to provide a systematic treatment of his subject. As printed, the work is obviously unfinished and deeply disorganized. It is made up of a series of numbered "Parts". Part I consists of a list of the heads or titles under which research on blood should be conducted, and a methodological statement on the use of heads in creating natural knowledge. Boyle identifies thirty heads for investigation. These include research into the colours, taste, odours, heat and inflammability of blood; analysis of its "Serous", "Fibrous" and "Red" parts, its "Spirit", "two Oyls", "Fixt Salt" and "Terra Damnata"; its specific gravity; the effects on it of various liquors and salts; its mechanical, chymical and medicinal uses; the differences between the blood of different groups of people, and the differences between human and animal blood. ${ }^{42}$ The aim of Part II, containing “Miscellaneous Experiments and Observations, about Humane Blood", is to realize this research. However, it consists of only twenty-three experimental accounts, referable between them to just nine of the thirty titles listed in Part I, and Boyle emphasizes their miscellaneity: "haste" has compelled him simply "to set down what occur'd to me in the Casual Order wherein they offer'd themselves". ${ }^{43}$

In the more sustained experimental sections which comprise Parts III and IV Boyle investigates the serum and spirit of human blood respectively. Boyle describes these sections as exemplary: "I thought fit in a couple of Subjects," he claims, "to give some instances of what I had thoughts to do on others." 44 However, this grouping

1998, pp. 504-10. For the negotiation of a further position, which attempts to do justice to both conscious and less conscious motives on Boyle's part, see Hunter, Scrupulosity, op. cit., note 32 above, ch. 7, while for a further account which seeks to link Boyle's statements with the rationale of his publications, see Harriet Knight, 'Organising natural knowledge in the seventeenth century: the works of Robert Boyle', University of London, $\mathrm{PhD}$ thesis, 2003,

ch. 4 .

${ }^{41}$ Works, vol. 10, pp. 5-6.

${ }^{42}$ Ibid., pp. 12-13.

${ }^{43}$ Ibid., pp. 6, 17 and passim.

${ }^{44}$ Ibid., p. 6. 


\section{Robert Boyle's Memoirs for the Natural History of Human Blood}

represents a departure from the order laid down in Part I, where neither of these is a single category (the fact that this material was initially routed to his Experimenta et observationes physicae may indicate that it originated separately and that the decision to include it here was a last minute one). Boyle attempts to reassert the value of the Part I list by explaining that the experiments in Part III are referable to either title sixteen or to title seventeen, but Part IV confirms the serum and spirit of blood as separate categories, with a list of subordinate heads into which research on the spirit of blood should be divided. A substantial 'Appendix' amplifies this disorderliness: it contains experiments which should apparently belong in Part II, but are not directed to any of the heads in particular. The appendix also includes three experiments referred to the section on serum and fifteen to that on spirit. ${ }^{45}$ Not only is Boyle's work on blood unfinished in the sense that it does not provide material under all of the heads listed as appropriate for consideration in a natural history of human blood; the information it does record is not even distributed according to its own instructions.

To some extent, the anomalies detailed above can be explained by considering the methodology Boyle discusses at length in Human blood. The preface is linked to writings on scientific method that Boyle compiled in the 1660s-particularly his (then unpublished) letter to Henry Oldenburg dated 13 June 1666 to which he alludes here, stating that "some passages" were derived from it. ${ }^{46}$ Boyle's preface lays out an explicitly Baconian process of inquiry, in which topics are investigated through the generation of sets of heads (or in "our illustrious Verulam's phrase" "Titles") under which data are collected. ${ }^{47}$ As Michael Hunter has shown in his study of the roots and rationale of Boyle's Baconianism, such lists of "topica particularia" were used by Bacon as a structure for two of his principal natural histories, the 'History of winds' and the 'History of life and death'. In addition, in his Parasceve or 'Preparative for a natural and experimental history', Bacon advocated the compilation of such lists more generally. From the 1660s, such lists became central to Boyle's own methodology: he used them to set an experimental agenda for himself and others, to clarify and structure his thoughts on given topics, and to provide frameworks for collecting and sorting miscellaneous data, as well as publishing at least three works (of which Human blood is one) substantially organized on their basis. ${ }^{48}$

Boyle's preface claims that natural historical investigations should begin with the compilation of a "first Order or Classis" of titles made as they "occurr'd readily enough to my thoughts" on an initial survey of the subject. This will not be definitive, Boyle warns, since it cannot be expected that anyone could devise "as direct and compendious ways of Indagation, and as good Methods of Digesting, and delivering what is discovered" before

\footnotetext{
${ }^{45}$ Ibid., pp. 30, 39ff., 78ff. It is perhaps also worth noting here that, although Boyle states in Part 1 that he had decided to omit consideration of the urine and other bodily fluids (see below, pp. 162-3), he nevertheless attaches a list of heads for a natural history of urine: ibid., pp. 14, 15-16.

${ }^{46}$ Ibid., p. 9; Correspondence, vol. 3, pp. 170-5. For an elucidation of and commentary on this text, see Peter Anstey and Michael Hunter, 'Robert Boyle's "Designe about natural history", , forthcoming.

${ }^{47}$ Works, vol. 10, p. 9.
}

\footnotetext{
${ }^{48}$ See Hunter, 'Robert Boyle and the early Royal Society', op. cit., note 19 above. For an edition of such heads as have survived only in manuscript form, see Michael Hunter (ed.), Robert Boyle's 'Heads' and 'Inquiries', Robert Boyle Project Occasional Papers, No. 1, Birkbeck, University of London, Robert Boyle Project, 2005 (available at http://www.bbk.ac.uk/boyle). See also Peter Anstey, 'Locke, Bacon, and natural history', Early Sci. Med., 2000, 7: 65-92, esp. 79-81 on

Human blood.
} 


\section{Harriet Knight and Michael Hunter}

carrying out a "studious Enquiry" into the given subject as afterwards. Given the impossibility of perfecting the order of the heads at this stage "one need not be too scrupulous about the enumerating, and marshalling the Particulars": it is more important to ensure "that the Titles should be various, and comprehensive enough, than that they should be nicely Methodical". Nor should they be written to satisfy a particular hypothesis. The emphasis here is on copia, rather than order; on generating information rather than producing a finalized account.

Crucially, the titles under which research is to be conducted must be adaptable to the subsequent findings of the research itself. In this way, an initial "first classis" may give way to an improved "second classis", which more accurately reflects the subject as investigations reveal it. The results of "Reading, Conference, Meditation" and most importantly performing "Tryals" will allow the naturalist "to frame another set of Titles, which may be called the Second, or (if no other interpose) the last Order or Classis of them which ... will be much more copious and better rang'd than the first." The discoveries made during the first phase of the project "may direct the Historian to range his Topics, or Titles in a better Order, and more natural Method, than those of the first Classis", subdividing and rearranging his categories as necessary. ${ }^{49}$ It is worth commenting here that this elaboration of Boyle's use of such "titles" is unique to this instance: in no other case did he advocate using a "first classis" and "second classis" of titles in this way. ${ }^{50}$

Following the construction of the revised "classis", the collected data "may be digested and framed into an Inchoate Natural History of the Subject they have relation to". Boyle emphasizes the continuing disorder: this is called "an Inchoate History to intimate, that even after all that has been already done, I think it too probable that the History will hereafter appear to have been rather begun then compleated". Nature and human industry are so fertile that Boyle anticipates "that the knowledg of the Subject of the History will from time to time be encreas'd, and so the History it self may be enlarged and corrected". It will therefore not "in many Ages, if ever it be at all, be made absolutely perfect". ${ }^{1}$ Boyle defends the "Appendix" to his printed book in this context, claiming that it contains items which had been omitted from the relevant title through "haste or oversight", along with "new Particulars" suggested by research which post-dated the compilation of the heads, and may not be directly referred to any of them, while nevertheless contributing to the subject. $^{52}$

The disorderliness of Boyle's work on blood, and particularly the confusion which arises from the failure to absorb all the material under the stated heads, becomes understandable if the work is considered as being in progress, rather than being enshrined in its final form in its printed state. Rather than presenting his Natural history of human blood as definitive, Boyle indicates that it represents an imperfect state of knowledge, which he anticipates will soon be superseded. He explains the provision of heads as an attempt to stimulate research

\footnotetext{
${ }^{49}$ Works, vol. 10, pp. 9-10.

${ }^{50}$ It is perhaps also worth noting Boyle's suggestion in ibid., p. 11, that a "middle Order, or Classis", between the "First" and the "Last" might be appropriate for topics that are "very comprehensive or very Difficult", examples of which he then gave, though the implication is that blood was not one of
}

these, since Boyle did not in fact use this intermediate category in Human blood, and it may be that this represents an otherwise lost remnant of the 1666 letter to Oldenburg on which he states that he here drew.

$$
\begin{aligned}
& { }^{51} \text { Ibid., p. } 11 . \\
& { }^{52} \text { Ibid., p. } 12 .
\end{aligned}
$$




\section{Robert Boyle's Memoirs for the Natural History of Human Blood}

by others in the field: to "direct those that want better Guides, what Enquiries to make, and to what Heads to refer, what they have found by Observation or Tryal", and "to propose some Example to those ... unpractis'd in drawing up Natural Histories". He presents his work on blood as part of a collaborative and ongoing project, rather than as a definitive account of its subject. While on the one hand he denigrates the heads as "but bare Titles" whose shortcomings must be supplied by the provision of data such as that on the serum and spirit of blood, on the other he considers them as "perhaps ... the usefullest part of the ensuing Papers". ${ }^{53}$ The text as published thus represents only a preliminary phase of the process of achieving natural knowledge laid out in the volume itself: its empty heads and copious research which cannot be reduced to the titles provided clearly embody the initial plan of research using the "first classis" of heads.

Boyle's sense of the printed work as an imperfect spur to future research is further emphasized in a 'Post-Script' which asks readers to verify the printed results, and claims that he has further particulars he could add, "if Time and Discretion would permit". Boyle asks his readers "peremptorily [to] require" him to publish further on the subject: he "may well hope" for such a request since even "a cursory review of a part only" of the printed work has suggested various ways of increasing the appendix. Boyle's proposed reform is not limited to increasing the number of observations: given "Health and Conveniency" he considers that the "Addenda" could "make way for a more copious, and less unaccurate, Scheme of Titles, such as those that in the first part (of the Memoirs) are call'd Titles of the Second Classis, or Order". 54

\section{Towards a Second Edition}

Equally significant - though hitherto unknown - is the evidence from his archive that Boyle actually carried out a substantial amount of work towards the second edition of Human blood proposed in the postscript to the first, and in doing so addressed many of the problems of the printed work. In addition to various accounts of experiments on blood, prefatory materials for the new edition survive in a number of copies, as do versions of an extended list of heads, or "second classis". Moreover, there is evidence that Boyle undertook the expansion of the printed tract almost immediately after its publication, and sustained it until his death in 1691. The earliest precise evidence we have of Boyle acting on his intentions occurs in a document entitled: 'A Catalogue of the Honourable Mr. Boyles Writings unpublish'd taken the $7^{\text {th }}$ of July 1684 '. This list includes the item: “Additions to the printed trace $[\mathrm{sic}]$ of Humane Blood". ${ }^{55}$ Further evidence that Boyle's additional research on blood was in progress during 1684 is provided by the juxtaposition of a copy of the advertisements about the extended list of heads and the experiments to be contained in the second edition, with manuscript versions of two passages printed in Boyle's Experiments and considerations about the porosity of bodies (1684). ${ }^{56}$ Porosity was reviewed in the Philosophical Transactions for 20 August 1684, and a copy was

\footnotetext{
${ }^{53}$ Ibid., p. 6.

${ }^{54}$ Ibid., pp. $95-6$.

${ }^{55}$ Works, vol. 14, pp. 341-2. In addition, 'An Appendix to the History of Human Blood' appears in 'A List of Mr Boyle's Philosophical Writings
}

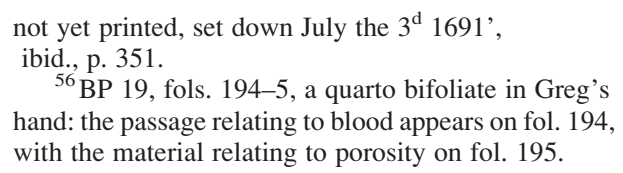




\section{Harriet Knight and Michael Hunter}

presented to the Royal Society on 29 October before it was registered in the Stationers' Company Register and advertised in the Term Catalogues for November $1684 .{ }^{57}$ Work on the second edition of Human blood was thus evidently underway within months of the publication of the first.

If Boyle's aim in publishing Human blood was to stimulate discussion, it worked. A report of the activities of the Dublin Philosophical Society received by the Royal Society in March 1684 recorded that Richard Bulkeley had produced a copy of Human blood and read out the heads from it, "promising to try some of the experiments therein mentioned, and not yet tried". 58 The Italian physician Marcello Malpighi, whose De polypo cordis (1666) had made crucial contributions to the understanding of blood, its composition and clotting, also took Boyle's promise of an expanded edition seriously, and Boyle later claimed Malpighi's prompting as the stimulus to his preparation of materials for a revised version. ${ }^{59}$ A Latin translation of Human blood was published in London in 1684, and was reprinted in Geneva in 1685 as part of the edition of Boyle's writings produced by the bookseller, Samuel de Tournes; subsequently, it was twice reissued with the date $1686 .{ }^{60}$ Writing to his fellow virtuoso, Prince Marcantonio Borghese, on 5 January 1686, Malpighi reported that he had seen the Geneva edition, and asked whether Borghese knew anything of the promised enlarged version. ${ }^{61}$ Having been informed by Borghese on 30 January 1686 that Boyle had not published any further on blood, ${ }^{62}$ Malpighi wrote on 6 February 1686 to his London contact, Carlo Antonio Ronchi, chaplain to Queen Mary of Modena. He thanked Ronchi for forwarding extra information from Boyle on the spirit of human blood, expressing his hope that Boyle would enlarge even further upon this and particularly its uses, and that he would publish a new edition of his work on blood as a whole. He also sent questions for Ronchi to raise with Boyle about the composition of blood. ${ }^{63}$ In a letter of the following day to Borghese, Malpighi related that Ronchi had sent him further details regarding the recipe for and use of spirit of human blood, and promised a still fuller report from Boyle. He suggested, without elaboration, that Boyle was doubtful about reprinting the work, and reported that he had encouraged Boyle to carry out further research on the composition of the blood. ${ }^{64}$ Malpighi's response from Boyle came in a letter from Ronchi dated 27 March

${ }^{57}$ Works, vol. 10, p. xxii.

${ }^{58}$ Birch, op. cit., note 9 above, vol. 4, p. 274.

${ }^{59}$ See Howard B Adelmann, Marcello Malpighi and the evolution of embryology, 5 vols, Ithaca and London, Cornell University Press, 1966, vol. 1, esp. pp 267-8 (see also pp. 497, 500-1); John M Forrester,

'Malpighi's De polypo cordis: an annotated translation', Med. Hist., 1995, 39: 477-92; and Domenico Bertoloni Meli, 'Blood, monsters, and necessity in Malpighi's De polypo cordis', Med. Hist., 2001, 45: 511-22.

${ }^{60}$ Fulton suggests that the London Latin edition (Fulton 146B) is very rare. The first Geneva edition is dated 1685 (Fulton 147); this was twice reissued dated 1686 (Fulton 148, 148A) Fulton, op. cit., note 1 above, pp. 101-2.

${ }^{61}$ The correspondence of Marcello Malpighi, ed. Howard B Adelmann, 5 vols, Ithaca and London,
Cornell University Press, 1975, vol. 3, pp. 1105-6: “Hò veduto il libro del Sig. Boyle stampato in Ginevra intitolato Apparatus ad Historiam Naturalem Sanguinis humani; non sò se quello, ch'ella hà sia la storia per extensum promesa nel suddetto libro, quando ciò fosse non recusarei le sue gratie." For Borghese, see ibid., vol. 3, p. 919n. Borghese had visited the Royal Society on 29 Nov. 1682: see Birch, op. cit., note 9, vol. 4, pp. $167,169-70)$.

${ }^{62}$ Correspondence of Marcello Malpighi, op. cit., note 61 above, vol. 3, p. 1133: "Del. Sigr. Boyle altro non è uscito che l'apparato alla storia naturale del Sangue ben vero che mi presuppongo anche in Inglese sia uscita la storia medesima."

${ }^{63}$ Ibid., pp. 1135-6. For Ronchi, see ibid., vol. 2, p. 790n. He had been a physician before becoming a priest.

${ }^{64}$ Ibid., p. 1141. 


\section{Robert Boyle's Memoirs for the Natural History of Human Blood}

1686. Here Ronchi reported that investigating the uses of spirit of blood lay outside Boyle's field of interest, but that Boyle had promised to ask various physicians to research the topic, and to pass their findings on to Malpighi. ${ }^{65}$ When Malpighi wrote to Borghese on 28 May 1686, he reported that he thought that Boyle would enlarge his book on blood. ${ }^{66}$

The later chronology of Boyle's renewed interest in blood can be traced by assigning dates to some of the material collected for the revised version. Passages copied from printed books provide one source: for example, an extract labelled "Pancratii Eunonymi Pyretologia mystica, s. de Febr. Petech. pag. 256" comes from a book not published until $1686 .{ }^{67}$ Dateable manuscripts allow us to trace Boyle's interest further. Two copies of a list of sub-headings investigating the putrefaction of blood date from c.1686 and c.1689. ${ }^{68}$ An experiment with serum is dated "May the 10. 1688" in Workdiary 37, while an experiment in the same sequence into the effect of drying on the weight of the fibrous part of blood is from autumn 1688. ${ }^{69}$ Five relevant entries appear in Workdiary 38, of which two are undated but must predate 27 March 1689, one was written on 10-11 June 1689, one on 10 June 1690, and one on 25 March 1691. ${ }^{70}$ The time-scale over which Boyle's interest persisted is illustrated by the recopying in the 1680s of an experiment recorded in Workdiary 21 two decades earlier. ${ }^{71}$

Boyle's interest in blood was thus sustained over a significant period of time, and his engagement after 1684 also went beyond the simple collection of extracts. Extensive preliminary materials for the second edition of Human blood survive in the Boyle Papers, giving a clear statement of Boyle's aims for the new edition. The first of these, a preface, provides a rationale for it. ${ }^{72}$ Boyle explains that having published on blood "about 2 years ago", he had thought he "might be allowd quite to dismiss that subject" (the draft version has: "dispenst with from medling any more" with it). Instead, he would have been happy to resign it to those with a professional interest in the subject, especially given that he had provided the list of heads. However, he reports that "notwithstanding its Imperfections", his work has been well received by "divers learned men, most of them strangers to me. And among these one of the eminentest \& famousest Physitians of this Age, hath been pleas'd, out of Italy, to sollicite me to make a second edition of that little Tract, with as great Enlargements as I could." ${ }^{, 73}$ This is clearly a reference to the correspondence with

\footnotetext{
${ }^{65}$ Ibid., p. 1158.

${ }^{66}$ Ibid., p. 1171.

${ }^{67}$ BP 18, fol. 31; Unpublished material, p. 13. The book cited is Pancratius Eunonymus, Pyretologia mystica, Padua, prelo Academico, 1686.

${ }^{68}$ MS 185, fol. 56; MS 189, fol. 149; Unpublished material, pp. xiii, 31 . These notebooks can be dated by internal dates and other clues.

${ }^{69}$ WD 37-81, 99a.

${ }^{70}$ WD $38-1,16,25,81,130$. Other materials may also have been lost from the archive: for example, BP 35 , fols. $127-8$, which comprises the index to a section of a workdiary which no longer survives (probably part of Workdiary 29) shows that this, too, contained various experiments on blood, including the following entries: "117 Blood swimming in water. 118 Experimt. of cogulating [sic] humane blood. 119 Other Exp.
}

with hum. blood. 120 Another, with spirit [of sal ammoniac].'”

${ }^{71}$ Workdiary $21-205$ is recopied in Bacon's hand with corrections by Greg (giving a date in the 1680s) in BP 18, fol. 18; Unpublished material, p. 5.

${ }^{72}$ Unpublished material, pp. 1-2. Two copies of this survive in the Boyle archive, a draft at MS 185, fols. 15-16, and a fair copy at BP 18, fol. 11 from which the quotations here are taken. For the full text of the prefatory material, see Unpublished material, pp. 1-3.

${ }^{73}$ This figure is tentatively identified as Malpighi by Hunter and Davis in The works of Boyle although no letter of relevant date from Malpighi to Boyle survives (Works, vol. 10, p. xvii). As we have seen, this anomaly is caused by Malpighi's use of Ronchi as an intermediary, and the identification can therefore be confirmed. 


\section{Harriet Knight and Michael Hunter}

Malpighi discussed above. Boyle goes on to explain that he has had neither the "leisure nor health" to comply fully, but has consented to "enlarge the Sett of titles" by adding topics "suggested to me, by things occurring after the first Articles of inquiry were printed off" and to augment the content "by Annexing to several of the Titles such Tryals \& Remarks, as I could find disperst here \& there in a Chaos of my own Experiments." He has not been able to obtain sufficient healthy blood to perform all of the experiments he would have liked, but regards the publication of further "scatterd notes, ... bundled up together" as providing "not unusefull hints" for future development since "the Subject (Humane Blood) thô of great importance, is not yet so cultivated, but that a great deal of room is left for usefull Additions."

Two copies of a further prefatory note about the new list of heads also survive in the archive. ${ }^{74}$ This list is particularly revealing in the light of Boyle's awareness of the imperfections of the first edition which we have already dealt with, since Boyle claims that even these revised heads are neither definitive nor strictly logical, and he does not therefore wish to give them the authority of calling them the "second classis", in contrast to which the printed heads would become the "first classis" in the overall scheme of his work on blood. Rather, he continues to emphasize that the list is provisional. He anticipates criticism of his chosen arrangement: "I scarce doubt but some will find fault with the Order, in which I have set down the Titles of the first Classis; and will object, that I have given the precedency to this or that, before some other to which it should have been postpon'd." His defence is on the basis of his experience (confirmed by extant manuscripts) of having drawn up the titles "more than once ... with alterations in their Order", with the chief aim "to make the Subjects be the more easily and clearly understood". He explicitly rejects "such a Logical Method, as some Ramist or other Dichotomiser would exact" since it would result in unevenly sized groups, and because, "provided the Titles be pertinent \& comprehensive enough, 'tis of no great importance, whether this or that be rank'd in the $3 \mathrm{~d}$ the 4 th or, if you will, the 10th place."

The final piece of prefatory material for the second edition of Human Blood closely echoes the postscript to the first and brings us to a discussion of Boyle's reformation of his content. His postscript had called for the appendix to be increased by both "designed Experiments, that is, such as have not yet been try'd, and yet seem worthy to be so" and by other "Succedaneous Experiments" which are to be performed on animal blood "in such Cases and Circumstances, wherein the Blood of Men, either cannot be had, or ought not be procured". 75 The relevant section of text is entitled "Design'd Experiments For the Second Edition Of the Natural History of Human Blood" and "Advertisements". ${ }^{76}$ It explains that there are two sorts of experiments: "the One Direct and Immediate, which may wel be try'd upon a Human Body or Blood itself; and the Other Succedaneous, ... wherein are substituted Bodys or Bloods of Brutes, in case wherein 'twere either unlawful, or inhuman, or too difficult to make Tryals upon those of Men." As might be expected, Boyle has taken the recommendations made in the postscript to his first edition as a starting point for his planned second edition.

${ }^{74}$ BP 18, fol. 12, and BP 19, fol. 194; Unpublished material, p. 2. The BP 19 version contains corrections which are incorporated in the fair copy in BP 18.

${ }^{75}$ Works, vol. 10, p. 96.
${ }^{76}$ BP 18, fol. 13; Unpublished material, p. 3. Further copies (both with insertions and corrections) exist at BP 18, fol. 14 and BP 19, fol. 194. 


\section{Robert Boyle's Memoirs for the Natural History of Human Blood}

In terms of reformation of content, the crucial relevant survival in the Boyle Papers is of various copies of an expanded list of heads for the investigation of blood. In the introductory note to Human blood in The works of Robert Boyle it was wrongly presumed that, because certain versions of the list that differed from that published in Human blood preceded its publication - notably BP 18, fols. 43-4 and 48 - all the others did too, and that Boyle had increasingly elaborated the list in the pre-publication period, prior to compressing it again. It is now clear that this was mistaken, and that it was subsequent to publication that Boyle expanded the thirty point list, as printed in 1684 , to a list with three preliminary and forty-two other titles. ${ }^{77}$

The heads added in the revised list reveal Boyle addressing the disorderliness of the printed work, and the omissions from it. These allow for the full inclusion of Boyle's own research under discrete headings, as opposed to its clustering in the appendix, and for the incorporation of research carried out by others in the 1670s. They mark his response to Malpighi's demands, and show him using the printed work of 1684 as a leaping-off point for further research, rather than seeing it as a record of achievement. In brief, the revisions show Boyle following the methodology detailed in the first edition for moving from a first towards a "second classis" of topics.

One group of new heads was intended to ensure that the second edition of Human blood could accommodate research carried out in the 1670s but omitted from the 1684 book. Head four asks "whether Human Blood consist of or contain, either Chyle separable in its pristine form, or a serum that serves but for a vehicle to the true Blood". In his paper presented to the Royal Society on 25 November 1675, Walter Needham had summarized and refuted J B van Helmont's suggestion that the serum is "an insipid liquor, void, as he thought, of any noble parts, only the companion, or rather vehicle of the blood, which served to dilute it in its motions". Needham accorded that role to the "phlegm of the serum" only: the serum itself he regarded as most closely resembling "the materia prima of Aristotle; a thing that is actually nothing, but potentially all things". Needham argued for a composite, and far more effective serum: "the proveditor-general [sic] of the body, the instrument of all the concoctions in it." ${ }^{, 78}$ With its echoes of his terminology, this title seems to respond directly to Needham's work.

\footnotetext{
${ }^{77}$ For Hunter and Davis' analysis, see Works, vol. 10 , p. xii. For the lists which appear to predate publication (BP 18, fols. 43-4, 48), see Unpublished material, pp. 20-3. Two copies of the list as published in Human blood survive at BP 18, fols. 42 and 54. There are three copies of the "expanded" list at BP 18, fols. $45 \mathrm{v}-46$; BP 18, fols. 49v-50; and BP 26, fol. 46; Unpublished material, pp. 28-31. In the latter, the items are unnumbered. The process whereby Boyle expanded the printed list to reach this version is elucidated in BP 18, fols. 56-7; Unpublished material, pp. 25-8. This lists "Primary Titles Additional", which are titles not present in the printed list which do appear in the longer list prepared for the second edition. The "Subtitles" listed here were originally referred to the relevant head in the printed list, using the numbers established there. These numbers were subsequently
}

replaced with a series which refer the subtitle to the relevant category in the second edition list. In only one case was the printed list more extensive than the 2 nd edition version: Item "7. Of the Specifick Gravity of Humane Blood entire" and "8. Of the Specifick Gravity of the two obvious Parts of Humane Blood, the Red (and Fibrous) and the Serous" in the printed edition are condensed in the second edition into "13. of the Specific Gravity of entire Human Blood \& that of its Consistent Part and of its Serum". For a table collating these lists, see Unpublished material, pp. 33-50.

${ }^{78}$ Needham in Birch, op. cit., note 9 above, vol. 3 , p. 237. For a discussion of Needham's insistence on the potency of serum, see Hall, op. cit., note 3 above, p. 446. See also Allen G Debus, The chemical philosophy. Paracelsian science and medicine in the sixteenth and seventeenth centuries, 2 vols, New York, Science 


\section{Harriet Knight and Michael Hunter}

In the new sixth head, Boyle addresses another of the areas of contemporary interest in blood that had previously been omitted, raising the topic "of the Constituent Parts of Human Blood as they are discoverable by the Microscope". The research accommodated here is van Leeuwenhoek's microscopic study of blood published in the Philosophical Transactions in 1674 which reported that blood "consists of small round globuls driven through a Crystalline humidity or water". ${ }^{79}$

In addition to responding to external stimuli, Boyle's new heads allow his own research on the serum and spirit of blood to be subsumed properly into the overall design of the work, in contrast to the rather clumsy way in which they had been incorporated in 1684 . The new twenty-second head, which makes the investigation of the serum a category in its own right, shows Boyle acting on his recommendation that the list of heads should be altered in the light of further research. Boyle's focus on the serum of the blood after 1684 is illustrated by the content of the forty-six paragraphs of text on blood which survive from this period, seventeen of which are cross-referenced to Boyle's list of heads via marginal numbers. The largest single group of items is keyed to entry twenty-two and discusses the serum. ${ }^{80}$ The second largest grouping, with eight entries, treats the spirit of human blood, to be discussed below. No other category has more than three entries referred to it.

Heads twenty-three to twenty-five also seem to respond to the proliferation of Boyle's own research on blood as presented in his printed work. The 'Appendix' to the printed edition contained a series of six experiments which discussed the effect on the colour of blood of adding various substances to it (for example lemon juice, alcalies, or spirit of vinegar). ${ }^{81}$ These were not attributed to any of the heads in the printed list, and perhaps represent the kind of material which Boyle hoped to accommodate under the new head twenty-three: "Of the Chymical Analysis of Human Blood according as severall Additaments are mixed with it." Insofar as this topic had been treated in the printed list, it was as part of the single category (no. 18) "Of the Artificial or Chymical Analysis of Humane Blood, and first of its Spirit". In the expanded list this is broken into three heads; number twenty-three (just quoted), number twenty-four, "Of the Chymical Analysis of Human Blood made without Additaments, and especially of the Order wherein the differing substances ascend in the first Distillation \& in Rectification", and number twenty-five, "of the Spirit of Human Blood". This expansion suggests that these topics had proved more complex than Boyle had anticipated. The rationale for the section on the spirit of blood may parallel that for the serum: while not a category in the printed heads, it is dealt with at length in the printed work and further in items surviving in the archive. Moreover, it is evident from Malpighi's correspondence that Boyle was specifically encouraged to research the spirit of blood further.

History Publications, 1977, vol. 2, p. 517, who fails to take seriously Boyle's claims that his published book was the result of earlier research, instead using it as evidence that van Helmont's ideas were still current in the $1680 \mathrm{~s}$, and that Boyle continued to support them despite the work of Hooke, Malpighi and Needham.

${ }^{79}$ Philos. Trans., 1674, 9: 23-5, on p. 23. See also van Leeuwenhoek's further article: ibid., 121-31.
${ }^{80}$ BP 18, fols. 18-39; Unpublished material, pp. 5-17. Those entries which deal with topics which occur in both the printed and second edition list are keyed to both, using roman numerals for the relevant head in the second edition, with arabic for the first.

${ }^{81}$ Experiments III-IX in Boyle's Appendix: Works, vol. 10, pp. 81-2. 


\section{Robert Boyle's Memoirs for the Natural History of Human Blood}

In addition to allowing the thorough incorporation of research findings annexed to the 1684 edition, the new set of heads made it possible for other topics which Boyle was actively researching to be brought to bear on the subject of blood. The new title at number thirty-one, "whether from Human Blood either fresh or putrefy'd, may be obtain'd a Noctilucal substance, that is a Matter shining without the help of External Light", evidently reflects Boyle's interest in luminescent substances as signalled in his publications on The aerial noctiluca (1680), and The icy noctiluca (1682). ${ }^{82}$ While these predate the first edition of Human blood, and his interest could theoretically have been incorporated in the printed heads, it seems likely that, as with the research by Needham and van Leeuwenhoekalso carried out early enough to have been considered in the printed Blood, but actually ignored until the planned second edition-Boyle's interest in luminescent substances postdated the initial phase of his researches into blood. Like other English virtuosi, he learned about the newly-discovered white phosphorus and the analogous "hermetic phosphorus" in the late 1670s through the specimens provided by the German chemists Johann Daniel Krafft, and Christian Adolph Balduin, and it was at this time that his first experiments on these substances were carried out. ${ }^{83}$

A final cluster of new heads shows Boyle expanding his list to include topics which had been explicitly excluded from the printed version, which had emphasized in its preface that it should not be regarded as comprehensive. ${ }^{84}$ These heads show a revision of his sense of the scope of the project, and reveal him using the published work as a basis for significant expansion. The first of these is to consider "the Process of Sanguification, or the Changes that the Aliment taken in at the Mouth undergoes to be turn'd into perfect Blood". In his preface to the first edition Boyle had explained that he would not be tracing the "Progress from the reception of the Aliments at the Mouth, to the full Elaboration", which would involve him in writing "the History of Sanguification as well as that of Blood." 85 Similarly, Boyle's printed preface had explicitly excluded the subject of what now became the second and third preliminary titles, warning that he would only treat blood "as 'tis compleatly elaborated, and that too, not as 'tis form'd in the Vessels of a living Body, but as it is Extravasated, and let out by the Lancet". Now, preliminary title two was "Of the Quality of this Liquor, of its continual Supplyes \& Absumtion, \& of its Proportion to the rest of the Human Body", while title three was "Of the Motion of the Blood \& of its Circulation". 86

Other acknowledged omissions of the printed work are also covered in the new list. The first of Boyle's "Titles of the first Order", which specifies that he will deal only with venal blood, represents the earliest occasion in relation to this project in which he specifies the difference between arterial and venal blood, although this had been a commonplace of research on blood since the earliest stage in Boyle's involvement in it in the 1650s. Title two addresses another new area: "the Difference between the Blood of living \& that of

\footnotetext{
${ }^{82}$ For the connection of this title with Boyle's published works on phosphorus, see also Works, vol. 10, p. xii n.

${ }^{83}$ For a full account of the experiments on phosphorus, see J V Golinski, 'A noble spectacle: phosphorus and the public cultures of science in the early Royal Society', Isis, 1989, 80: 11-39. For the
}

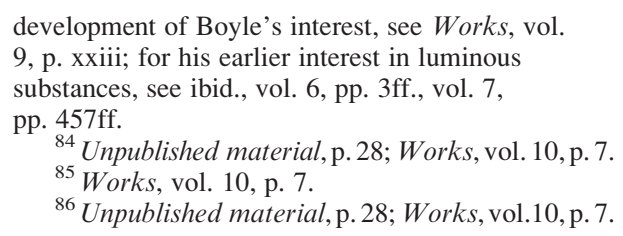




\section{Harriet Knight and Michael Hunter}

dead men, whether it be within the Veins or out of them." By contrast, the printed work had limited itself to "such Humane Blood, as was taken from sound Persons". ${ }^{87}$

The third title in Boyle's extended version: "Whether the Blood consist of those differing substances, that Physicians commonly suppose to convene in it, viz. Phlegm, Bile, Melancholy \& Blood strictly so call'd" perhaps echoes his reservations about orthodox medical ideas as reflected in his polemic about medical practice, the suppression of which (as we have seen) may have been a trigger to the publication of Human blood. Though it seems likely that Boyle was expecting a negative answer from his investigation, it may reflect the fact that Malpighi, who seems to have provided the impetus for this reworking, was a physician, and it is possible that his interest led Boyle to wish to explore the current state of medical opinion more explicitly in the second than in the first edition. It may also reflect Boyle's hope (reported via Ronchi in his correspondence with Malpighi) that more enlightened physicians would help him to investigate the matter. ${ }^{88}$ In addition, Boyle's printed work on blood had focused more on chemical than medical issues, and this title might be seen as an attempt to redress that imbalance. ${ }^{89}$

The new category at number thirty-three represents a further expansion of the coverage of Boyle's research. Abandoning the limitation of his research to the investigation of the blood of humans, and sound ones at that, Boyle here moves onto a discussion of animal blood, proposing a category of experiments partly to be made using his air-pump to discover "what Change (if any) the Blood of Animals strangled by suffocation, or in the Exhausting Engine, or drown'd in Water, or in Milk, or in Spirit of Wine, or in Chymical Oyls, or suffocated in Mercury, will have produc'd in it, by their peculiar kinds of Death." These proposals clearly belong to the category of "succedaneous" experiments discussed above as having been identified as ripe for research in the postscript to the printed work and discussed in the advertisement for the second edition. ${ }^{90}$

Heads thirty-nine to forty-one all deal with the relationship between blood and other bodily productions. Thirty-nine inquires into "the Natural \& Regular Usefull Productions of the Blood, such as are suppos'd to be Spirits Animal \& Vital, the Gall, the Succus Pancreaticus, the Serum, the Lympha \&c., \& also of those that are held to be but Excrementitious as Urine, Earwax, Spittle, Tears \&c." Number forty considers "whether Milk be produc'd of the Blood as its Material Cause", while forty-one discusses "whether any, or (if any) what Difference may be found by Chymical Analysis ( $\&$ otherwise) betwixt Blood \& those other Juices of the Body that are suppos'd to be further Elaborations of it, such as are Milk, Sperm, Gall \&c." This relates to van Leeuwenhoek's treatment of blood in conjunction with milk, hair, brain, flesh, liver, sweat, spittle, fat and tears in two issues of the Philosophical Transactions in 1674. ${ }^{91}$ In the published Human blood Boyle had stated that, though he "had once some Thoughts" of preparing a natural history "of other Liquors of a humane Body, as well as the Blood; I mean such as the Gall, the Lympha, the Succus Pancreaticus, Spittle, Urine, Milk, \&c.", he "quickly perceiv'd" that "it was fit for me to resign such Tasks to Physicians" (an echo of the sense of territoriality reflected in his

\footnotetext{
${ }^{87}$ Unpublished material, p. 28; Works, vol. 10, p. 7.

${ }^{88}$ See Hunter, Scrupulosity, op. cit., note 32 above, ch. 8, passim.
}

\footnotetext{
${ }^{89}$ See Büttner, op. cit, note 4 above, p. 195.

${ }^{90}$ See above, p. 158.

${ }^{91}$ Philos. Trans., 1674, 9: 23-5, 121-31.
} 


\section{Robert Boyle's Memoirs for the Natural History of Human Blood}

comments on his suppressed medical polemic); he therefore excluded them (though, slightly contradictorily, he had included a set of heads for urine). ${ }^{92}$ Now, the inclusion of this and related material was justified in its own right. In summary, Boyle's new list of heads reveals a clear agenda of revising and expanding the printed work, an agenda which shows his awareness that, by issuing a provisional version of his work in print, he had provided a useful stimulus to fresh research.

\section{Conclusions}

By considering the complete history of Boyle's research into blood, rather than merely his printed contribution to the topic, we are able not only to re-evaluate his significance in that field, but to reconsider his attitude to the role of print more generally. Boyle's insistence in his preface on the flaws of Human blood as published, his statement of its provisional status according to the Baconian methodology there outlined, and the survival of copious material designed for a second edition, all warn against any presumption that Boyle regarded print as a medium which necessarily stabilized and enshrined completed research. In this instance, matters are complicated by the fact that Boyle's reasons for publishing the book exactly when he did are frustratingly elusive, and at least one of his motives was evidently to gain credit for research carried out long before. But the manner in which he presented it, and the way in which he almost immediately began work on an improved version, suggests a different interpretation. Rather, it implies that he saw print not as a goal in itself but as a medium appropriate for the dissemination of work in progress and for recording unmethodized results which required supplementation and rearrangement-as likely in manuscript as in print-for their significance to be realized.

Indeed, although the beneficiary of print for his international reputation, Boyle seems to have been more ambivalent towards the medium than many commentators have allowed. To a surprising extent, he apparently saw his corpus as transcending what happened to be made available in printed form: in Human blood, for instance, his opening remarks explicitly allude to his "(unpublish'd)" letter to Oldenburg "about the way of compileing a Natural History", as if publication was not really significant to the status of a work, and elsewhere he refers his readers-often rather vaguely - to other papers which never appeared in print and may never have been intended to. ${ }^{93}$ It is as if, for him, the boundary between his published and unpublished writings was not a particularly important one: contingent circumstances often made publication appropriate, but there was nothing inevitable about things appearing in print, nor anything sacrosanct about them once they had. For him, both published and unpublished works formed part of a larger corpus which he was constantly refining and developing. ${ }^{94}$

\footnotetext{
${ }^{92}$ Boyle Works, vol. 10, pp. 14, 15-16, and see above, p. 153; Hunter, Scrupulosity, op. cit., note 32 above, pp. 177-81. A list of twenty-five heads relating to the Gall also survives in the Boyle Papers: BP 18, fol. 47; Unpublished material, p. 32.

${ }^{93}$ Works, vol. 10 , pp. 9, 29, 36, 39, 65. See also pp. $35,46,85,90$.
}

\footnotetext{
${ }^{94}$ This is borne out by his lists of his writings from the 1660s onwards, perhaps especially 'The Order of My Severall Treatises' and the verse mnemonic based on it: see Works, vol. 14, pp. 331-2, 335-6. Cf. ibid., pp. 345-6, which similarly mingle published and unpublished material.
} 


\section{Harriet Knight and Michael Hunter}

Yet insofar as Boyle used print, he did so in a manner which is easily misunderstood. Adrian Johns has criticized Elizabeth Eisenstein and others for overemphasizing the "fixity" of print when in fact circumstances beyond their control often thwarted the attempts of natural philosophers like Boyle to achieve the credibility that print entailed. Ironically, Johns himself shares Eisenstein's presumption that such fixity was Boyle's goal, whatever the problems he encountered in realizing it. ${ }^{95}$ Yet what Johns fails to acknowledge is the extent to which Boyle emphasized and exploited the flexibility of his chosen modes of publication, evidently relishing aspects of the contingent nature of print which served his intellectual purposes. This was already in evidence in the way in which his experience of contributing to Philosophical Transactions in the 1660s seems to have inspired a programme of publication on his part in the 1670s in the form of disparate "Tracts" which stressed the provisional, intermediate nature of what he published by such means. ${ }^{96}$

The situation with Human blood is comparable, as revealed by the evidence concerning its rationale and Boyle's plans to update and improve it that has been expounded here. In the published work, Boyle anticipates the book's unfavourable reception, but defends it as a necessary early phase in a larger development: he invokes an "enlightned Posterity" to whom "the Discoveries and Performances, upon which the present Age most values it self, will appear so easy, or so inconsiderable to them, that they will be tempted to wonder, that things to them so obvious, should lye so long conceal'd to us, or be so much priz'd by us". This will result in "some kind of disdainful Pity" unless future generations have the "equity" and "generous gratitude" to see Boyle's generation as "breaking the Ice, and smoothing the way for them, and thereby contributing to those Advantages, that have enabled them so much to surpass us". ${ }^{97}$ To an extent this may have been disingenuous; after all, in his publication of 1684, Boyle failed to consider the developments of the previous decade, and in that sense it was not defensible to claim that his publication reflected the current state of knowledge. However, such a future-oriented view of research, in which the individual contribution is always subordinated to potential advances at a later date, does make an untimely, unfinished contribution like Boyle's printed Human blood comprehensible. Both the edition he printed in 1684, and the modified version he prepared later in the 1680s, are presented to their readers less as monuments to completed research than as schemes for future improvement. Without detailed attention to Boyle's unpublished papers, the significance of his works as printed cannot be properly understood.

\footnotetext{
${ }^{95}$ Johns, op. cit., note 40 above, see index sv 'fixity', criticizing Elizabeth L Eisenstein, The printing press as an agent of change, Cambridge University Press, 1979, 2 vols. See further Knight, 'Designed instability', op. cit., note 5 above.
}

\footnotetext{
${ }^{96}$ See Works, vol. 1, pp. xxxvii-xxxviii; Knight, 'Organising natural knowledge', op. cit., note 40 above, pp. $183 \mathrm{ff}$.

${ }^{97}$ Works, vol. 10, pp. 6-7, 96-7.
} 